\title{
Review on halal forensic: a focus on DNA-based methods for pork authentication
}

\author{
${ }^{1,2}$ Yusop, M.H.M., and ${ }^{1}$ Bakar, M.F.A. \\ ${ }^{1}$ Faculty of Applied Sciences and Technology, Universiti Tun Hussein Onn Malaysia (UTHM), Hub \\ Pendidikan Tinggi Pagoh, KM1, Jalan Panchor, 84600, Muar, Johor, Malaysia \\ ${ }^{2}$ Faculty of Food Science and Nutrition, Universiti Malaysia Sabah, Jalan UMS, 88400 Kota Kinabalu, \\ Sabah, Malaysia
}

\begin{abstract}
Article history:
Received: 21 April 2020

Received in revised form: 26

May 2020

Accepted: 31 May 2020

Available Online: 20 August 2020
\end{abstract}

Keywords:

Halal forensic,

Pork authentication,

DNA-based method

\section{DOI:}

https://doi.org/10.26656/fr.2017.4(6).180

\begin{abstract}
Food product authentication is important at every level of the food manufacturing process, starting from raw materials until finished products. Authentication also plays an important role in assuring accurate food labelling, which is required to help consumers select suitable types of food products. Food adulteration is one of the vital issues addressed by halal authentication, especially for food products that contain pig traces or porcine ingredients. Various methods that aim to guarantee the authenticity of foods have been developed over the past years. In this article, a short review of recent food analytical methods related to authenticity studies, with special regard to pork identification, is provided. The focus of this review is DNA-based methods, which have gained the interest of the scientific community. The specificity, sensitivity and fast and high throughput of the methods are highlighted. In the present case, methods that are capable of detecting pork by using DNA barcode, polymerase chain reaction (PCR)-restriction fragment length polymorphism, conventional PCR, real-time PCR and isothermal amplification are discussed. Although PCR is the most popular method, recent studies have shown that isothermal amplification is a potential alternative because it is rapid, simple and does not require the use of any complicated instruments, such as a thermal cycler and sequencer.
\end{abstract}

\section{Introduction}

Food adulteration is a growing global problem that is increasingly being addressed through the authentication of ingredients via laboratory techniques. For many years, the authentication and adulteration of food products and analysis methods are well-known issues in food science. Moreover, these issues, which could be deliberate or accidental, are commonly faced by food manufacturers. Quality problems for foodstuffs with a high intrinsic commercial value. For that reason, observing adulteration practices has become crucial to protect food industries and consumers from fraud and deception (Marikkar et al., 2001).

Adulteration is defined as the act of intentionally defiling the quality and safety of food offered for sale either through admixture or substitution of inferior substances. It involves the removal of some valuable ingredients, tampering or misrepresentation of food. Another problem is that food packaging may contain false or misleading statements that claim authenticity; the word 'authentic' is normally defined as trustworthy, reliable and of undisputed genuine and origin (El Sheikha, 2019). Foodstuffs generally have a plant or animal origin. Unintentional cross-contamination is difficult to avoid in modern mass production and complicated handling processes. Thus, finding a successful method of detecting animal or plant species is the main issue for food authenticity (Luthy, 1999).

Food labelling regulations prohibit fraudulent substitution of high-value meat with lower-value meat in meat products (Johnson, 2014). Undeclared species in meat products may pose a possible health risk to consumers who have allergies to specific ingredients. Food adulteration of processed meat products has become a widespread issue in retail markets. The practice of mixing undeclared species is more frequently used for processed and cooked products than for raw products. Furthermore, because of its similar texture and colour and its lower value, pork is a potential source for adulteration of higher-value meat such as veal and beef (Chen et al., 1998). 
As a common practice, most countries perform adulteration by substituting meats and fats with meat from different origins or species when processing food products. These issues are serious and a cause of worry among people, particularly in relation to unclear or improper labelling, substitution with cheaper meats or religious specifications such as halal food for Muslim and kosher for Jews. The detection of animal species is difficult when meat products are involved in thermal processing because of protein denaturation. Another major problem is lard usage in meat products (Montiel Sosa et al., 2000). Thus, the authentication of food products is important for labelling purposes and assessment of value. The animal or plant species in a food product often determines what it can be called by the manufacturer, its price and even whether consumers are willing to purchase it. Authentication is vital to fair competition among traders and to assure customers of accurate labelling (Ram et al., 1996).

In this article, a short review of recent food analytical methods related to authenticity studies, with focus on porcine DNA identification, is provided. This review focuses on DNA-based methods, which have attracted the interest of the scientific community. The strengths and weaknesses of the methods are discussed, along with the methods capable of detecting pork in food, such as DNA barcode, polymerase chain reaction (PCR)-restriction fragment length polymorphism (RFLP), conventional PCR, real-time PCR and isothermal amplification.

\section{Recent methods of identifying pork in food}

Methods that are currently used for pork identification include protein isoelectric focusing (IEF) in polyacrylamide gels (Różycki et al., 2018) and agar gel immunodiffusion assays (Hsieh et al., 1995). Serological tests are specific and sensitive, but crossreaction of closely related species cannot be ruled out. These problems can be solved with methods based on the presence of species-specific DNA sequence in meat detected by DNA hybridisation (Hartati et al., 2019) or PCR (Cai et al., 2012; Yusop et al., 2012).

The mixture of animal species in food can be detected through various methods based on the type of products (Bansal et al., 2015). Several analytical methods are derived from the measurement of physical or chemical properties of specific components, such as proteins, lipids and sterols, in the products. The lipidbased analysis is used to analyse specific lipid classes in food products, while protein-based analysis is used to analyse specific protein classes (Cordella et al., 2002; Rohman and Fadzillah, 2018).
Among the various detection techniques, the use of DNA-based molecular tools may be more suitable for the detection of mixtures in animal and plant source materials, especially when the mixture is a biological material. Techniques that utilise the analysis and manipulation of DNA, RNA, protein or lipids have become an important part of molecular, biochemical and genetic biology. The discrimination of substances from pure foods can be easily accomplished by molecular markers because the mixture and pure foods exhibit physical similarities. A few strategies are used to detect mixtures by using DNA-based methods, such as DNA barcode, PCR and isothermal amplification method (Bansal et al., 2015).

\subsection{DNA Barcode}

DNA barcode is a molecular phylogenetic method that uses short DNA markers present in the organism as a proxy for the identification of their offspring. This method is widely used in the field of food science and technology (Ardura et al., 2010; Khaksar et al., 2015). An ideal barcode requires two important features: high descent and high resolution (Hebert et al., 2003; Galimberti et al., 2013). High-throughput sequencing refers to the amplification of the selected genetic region as the DNA code in the extended descent panel. The high resolution ensures the identification of other lineages on the basis of specific differences in the sequence of DNA codes. As a key principle, DNA coding regions need to have low intraspecific variability and high interspecification (Galimberti et al., 2013). DNA barcode is effective in detecting both the source and quality of raw materials, as well as detecting mixtures such as mixing products of other breeds in the food industry chain. However, its potential is based on the molecular variation of the organism, and high resolution can be achieved when the organism has low intraspecific polymorphisms that can increase its sensitivity. DNA barcode has been used to identify a wide range of raw materials and food commodities and to detect allergycausing or toxic substances in a food matrix Hebert et al., 2003; Casiraghi et al., 2010; Galimberti et al., 2013).

Naaum et al. (2018) used DNA barcode together with droplet digital PCR to detect undeclared animal species in sausage products at a retail market in Canada. The primers that were used targeted the mitochondrial cytochrome oxidase subunit I (COI) gene. One of the advantages of using mitochondrial gene is the higher copy number present in one cell. It also suitable for qualitative approaches such as DNA barcode, thereby increasing sensitivity to the point where low DNA template concentration can be detected. The test found that seven out of twenty-seven beef sausage samples 
contained pork, with two of these containing more than $5 \%$ pork (Naaum et al., 2018). DNA codes can be used in different contexts and by different operators because of its many uses. DNA coding is likely to be a routine test in many areas, especially in the field of quality control. However, DNA barcoding techniques require a long time for DNA amplification and sequencing. It also needs expensive instruments such as a thermal cycler and sequencer (Gao et al., 2019).

\subsection{PCR}

PCR was created by Mullis (1983). Although this biotechnology was developed in the 1980s, PCR has played an important role in many scientific studies and has been reliable in various aspects of biology and medical sciences (Kumar et al., 2015). The main components required for successful PCR amplification are a DNA template, a pair of primers that complement the target sequence, deoxynucleotides triphosphate and chemical buffers. Two important innovations in PCR have been achieved, namely, the discovery of thermal stable DNA polymerase enzyme and thermal cycler machine (Sulaiman and Muid, 2009).

Generally, DNA polymerase could be found in all living organisms. However, its structure may be highly destroyed if exposed to high temperatures during a PCR reaction. This condition occurs during the initial step of PCR, which is the denaturation of double-stranded DNA at $95^{\circ} \mathrm{C}$. As the DNA polymerase is destroyed, it should be added manually for each cycle of PCR. This issue is the main reason PCR needs thermal stable DNA polymerase such as Taq polymerase (Chapman et al., 2012). The Taq polymerase enzyme comes from a bacterium known as Thermus aquaticus. The function of DNA polymerase is to generate new DNA sequences from nucleotides by using a single strand of DNA as a template (Avison, 2008). Next, thermal cycler machines used in PCR techniques are developed to control the heating and cooling of PCR reagents on the basis of a set of temperature steps. Thermal cycler machines are important because they physically separate two DNA strand molecules that have a double-helix structure during DNA denaturation (Avison, 2008; Regan et al., 2012).

PCR has three basic steps: denaturation, annealing and extension. All three steps are usually repeated for 30 to 40 cycles. The main function of the denaturation step is to separate double-stranded DNA into a single DNA strand at a high temperature of about $95^{\circ} \mathrm{C}$. Afterwards, at $50-65^{\circ} \mathrm{C}$, the annealing step begins. The annealing step occurs when the primer begins to attach to the single strand of the target DNA. Extension steps at $72^{\circ} \mathrm{C}$ will allow the polymerase enzyme to work effectively. The
DNA template will attach to the primer and form a double-stranded DNA. The molecules of the two DNA strands are then amplified into two copies through one cycle. These two copies are then passed through the amplification process in the next cycle, and the cycle is repeated several times. As a result, PCR produces many copies and expands exponentially (Avison, 2008; Regan et al., 2012).

\subsection{PCR-RFLP}

PCR-RFLP is a technique by which closely related species can be distinguished by using pattern analysis generated from the exclusion restriction of their DNA. If two different species are present in the cleavage region by specific exclusion restrictions, then the length of the produced fragment will be different from the DNA digested for the enzyme blocker. Differences in the produced patterns can be used to distinguish species (variations) from one another (Levin et al., 2018). PCRRFLP techniques are widely used in the identification of species of the food source (Zeng et al., 2018). Ali et al. (2011) used PCR-RFLP technique with a very short length (109 bp) of PCR amplicon to detect pork in meat products. The sensitivity achieved by this method is $0.0001 \mathrm{ng}$ of porcine DNA. This technique was later widely applied for species determination in accordance with PCR-based methods (Lin et al., 2014). Kušec et al. (2017) used HaeIII restriction enzyme to identify pork in dry sausages. A 359 bp cytochrome b PCR product was cut into fragments of 74, 132 and 153 by the enzyme. The site was absent from the pork product; thus, the same PCR product would remain uncut when enzymes $R s a \mathrm{I}$ and Hinfl were used. The difference was visualised by agarose gel electrophoresis (Kušec et al., 2017). Common genes used for PCR-RFLP are cytochrome b gene and other mitochondrial genes for different species identification (Maede, 2006). In general, RFLP analysis can be performed to solve specification problems. However, RFLP requires additional costs for enzyme inhibitors, longevity and gel electrophoresis. Furthermore, RFLP cannot be used if the blocking region is not present in the desired PCR product. Therefore, product analysis using PCR-RFLP is complicated (Ali et al., 2012).

\subsection{Conventional PCR}

Conventional PCR is also known as traditional PCR because many types of modern PCR have been introduced in line with current technological development, such as real-time PCR or quantitative PCR (qPCR) (Pestana et al., 2010). This method requires a long time because the PCR reaction needs to be finished first before the post-PCR analysis can be conducted. However, although it has disadvantages in terms of time 
consumption, it is still an option for most people because it is more cost-effective and affordable to perform in the laboratory compared with qPCR (Cheng et al., 2016). Conventional PCR techniques have been modified to extend their use and versatility. The possible use in the same reaction on a pair of primers with direct amplification for multiple DNA targets is called multiplex PCR. Thus, more than one DNA sequence can be synthesised in the same process (Paiva-Cavalcanti et al., 2010).

Species-specific PCR utilises primer pairs for amplification of specific DNA sequences for selected targeting species. Designing species-specific primers play an important role in the PCR technique. One of the important criteria for primers that need to be taken into account to ensure a successful assay is that the DNA templates and primer pairs need to complement each other so that the 3'-5' oligonucleotide primer can anneal to the template and subsequently replicate. This condition can be achieved by analysing the in silico specificity of the primer oligonucleotide sequence at the targeted DNA region before designing the primer (Avison, 2008). Several studies that used conventional PCR to detect porcine DNA in food were conducted (Aida et al., 2005; Che Man et al., 2007; Karabasanavar et al., 2014; Hafidz et al., 2020). Although this technique provides high sensitivity and specification, some disadvantages exist, including the need for agarose gel electrophoresis, the risk of contamination, the inability to obtain a quantitative result and the need for harmful reagents such as ethidium bromide, which may be detrimental to the health of the analyst (Staggemeier et al., 2015).

\subsection{Real-time PCR}

Real-time PCR or qPCR are used to quantitate the initial number of template copies in biological samples. The copies are naturally present initially in such a low quantity or concentration that it is not possible to measure them. Through the amplification process of qPCR, a sufficient sample (and signal proportional to that sample) is generated for quantitative measurement. During the amplification cycles in which the reagents of qPCR are present in great excess, the amplification process performs near full exponential efficiency. Given a sensitivity that is sufficient for detection during the exponential period, the cycle at which the measured signal (proportional to the template copy number) rises above the background is repeatedly related to the initial template copy number (Sawyer et al., 2003).

A threshold signal level is defined as the point at which the signal has risen above the measurement noise. The cycle at which each curve crosses the threshold is defined as the quantification cycle $(\mathrm{Cq})$. The $\mathrm{Cq}$ is plotted against the $\log$ of the starting template number. Dilution series such as this one is typically run as standard curves along with samples of an unknown quantity. Through a comparison of the $\mathrm{Cq}$ of the unknown with those of the standards, quantitation can be performed (Wang, Chen and $\mathrm{Xu}, 2006$ ). The method of manual threshold definition and calculation of the intersection point of the amplification curves with the threshold has been traditionally used as a means of generating data from which to interpolate the starting copy quantity of the unknown sample. More recently, introduced variations on this method are more amenable to complete automation and less susceptible to instrument drift. These method centres on the use of the first derivative of the amplification signal. For these methods, the crossing point is defined as the cycle where the first derivative reaches a maximum. This point corresponds to the last cycle before amplification efficiency starts to decline (Wolf and Lüthy, (2001).

Two strategies are employed in creating standard curves. For absolute quantitation, a set of standard curves must be generated from a dilution series that began with a sample whose starting copy number was known. Absolute quantitation of this reference sample is typically performed by absorbance measurements. In addition to careful absorbance measurement, accurate pipetting is needed in absolute quantitation to create the dilution series (Wang, Zhu and Levy, 2006). Relative quantitation is an alternative for which standard curve preparation is less difficult. In this case, the experimental sample quantitation is expressed only relative to some basis samples. Basis samples can include stock DNA or RNA. Another sample is the use of the DNA and RNA from an untreated control subject. Housekeeping genes are frequently used in qPCR as a reference standard for RNA quantitation (Bustin, 2002).

The nature of qPCR enables the exclusion of very high amplification levels such as electrophoresis gel preparation. Many studies have used qPCR to detect porcine DNA in food (Yusop et al., 2012; Soares et al., 2013; Ali et al., 2015). Therefore, the advantage of qPCR over conventional PCR is its speed and quantification ability (Paiva-Cavalcanti et al., 2010). However, qPCR requires an expensive digital thermal cycler, which could detect fluorescence signals from a labelled DNA probe or intercalating dyes during the thermal amplification step (Yusop et al., 2012).

\subsection{DNA Isothermal amplification method}

In recent years, the DNA isothermal amplification method has achieved promising DNA detection in many applications, especially in food safety (Gao et al., 2017; 
Geng et al., 2018; Guo et al., 2019). One of the isothermal amplification methods is recombinase polymerase amplification (RPA), which uses lowtemperature isothermal amplification that couples the recombinase-oligonucleotide primer through the identification of complementary target sequences within double-stranded DNA (Piepenburg et al., 2006; Zanoli et al., 2013; Yan et al., 2014). Once the complementary target sequence is identified, the complex of the recombinase-primer splits the DNA strands, consequently allowing the primer and target sequence to anneal (Li et al., 2019).

RPA is different from PCR, which involves the denaturation step under high temperature to separate double-stranded DNA. It uses enzymatic reaction (recombinase), similar to the chemistry of helicasedependent amplification, which uses helicase to separate double-stranded DNA (Li and Macdonald, 2015). Singlestranded DNA-binding proteins assist in the hybridisation process by stabilising the displaced DNA strand, and polymerisation occurs following the formation of a primer-DNA complex (Yan et al., 2014). If the sample contains a target sequence, then the DNA polymerase enzyme (Bacillus subtilis Pol I, Bsu) elongates and replicates by using the single-stranded DNA template (Murinda et al., 2014; Yan et al., 2014; Li and Macdonald, 2015).

Similar to PCR, exponential amplification is achieved because of the two copies of newly synthesised duplex DNA act as templates for subsequent cycles (Yan et al., 2014). Fortunately, during amplification, RPA uses only two primers (forward and reverse), unlike other isothermal detection methods, such as loopmediated isothermal amplification, which needs four primers along with two additional loop primers (Kersting et al., 2014; Santiago-Felipe et al., 2014). Moreover, real -time monitoring is possible if a fluorescent probe is used, as in real-time PCR (Piepenburg et al., 2006). In this process, the probe is degraded following hybridisation, later releasing a fluorophore signal. The amount of fluorophore present increases as amplification continues, which consequently allows real-time measurement and observation (Piepenburg et al., 2006; Murinda et al., 2014). Recently, a method has been developed using RPA for the detection of five animal species, including pig, and SYBR Green I was used to visualising the RPA amplicons. SYBR Green I is one of the commonly used intercalating dyes to monitor the assay in real time. The sensitivity of the assay for porcine DNA detection is $10^{2}$ copies $/ \mu 1$ (Cao et al., 2018).

\section{Conclusion}

DNA-based methods have the needed sensitivity and specificity for porcine DNA detection in food products. This approach is well suited for confirming halal authentication in the food industry. PCR is the most common method among all porcine DNA identification methods. However, isothermal DNA amplification can be a better alternative to PCR because of its simplicity, and it does not involve a thermal cycler and is able to achieve rapid detection. More studies that use RPA as a tool for species detection and halal food authentication should be conducted.

\section{Conflict of interest}

The authors declare no conflict of interest.

\section{Acknowledgments}

The researcher would like to acknowledge research fund E15501 Research Management Centre, University Tun Hussein Onn Malaysia (UTHM) and Universiti Malaysia Sabah for providing research grants and facilities for research purposes. Special thanks to all who helped in completing this research.

\section{References}

Aida, A.A., Che Man, Y.B., Wong, C.M.V.L., Raha A.R. and Son, R. (2005). Analysis of raw meats and fats of pigs using polymerase chain reaction for Halal authentication. Meat Science, 69(1), 47-52. https:// doi.org/10.1016/j.meatsci.2004.06.020

Ali, M.E., Hashim, U., Dhahi, T.S., Mustafa, S., Che Man, Y.B. and Latif, M.A. (2012). Analysis of pork adulteration in commercial burgers targeting porcine -specific mitochondrial cytochrome $b$ gene by TaqMan probe real-time polymerase chain reaction. Food Analytical Methods, 5, 784-794. https:// doi.org/10.1007/s12161-011-9311-4

Ali, M.E., Razzak, M.A., Hamid, S.B.A., Mahfujur Rahman Md., Al Amin Md., Rashid, N.R.A. and Asing, A. (2015). Multiplex PCR assay for the detection of five meat species forbidden in Islamic foods. Food Chemistry, 177, 214-224. https:// doi.org/10.1016/j.foodchem.2014.12.098

Ardura, A., Linde, A.R., Moreira, J.C. and GarciaVazquez, E. (2010). DNA barcoding for conservation and management of Amazonian commercial fish. Biological Conservation, 143(6), $1438-1443$. https://doi.org/10.1016/ j.biocon.2010.03.019

Avison, M.B. (Ed.) (2008). PCR-Based Methods for Measuring Transcript Levels. Measuring Gene 
Expression. p. 167-189. London: Taylor and Francis Group. https://doi.org/10.4324/9780203889879

Bansal, S., Singh, A., Mangal, M., Mangal, A.K. and Kumar, S. (2015). Food adulteration: Sources, health risks, and detection methods. Critical Reviews in Food Science and Nutrition, 57(6), 1174-1189. https://doi.org/10.1080/10408398.2014.967834

Bustin, S.A. (2002). Quantification of mRNA using realtime reverse transcription PCR (RT-PCR): trends and problems. Journal of Molecular Endocrinology, 29(1), 23-39. https://doi.org/10.1677/jme.0.0290023

Cai, H., Gu, X., Scanlan, M.S., Ramatlapeng, D.H. and Lively, C.R. (2012). Real-time PCR assays for detection and quantitation of porcine and bovine DNA in gelatin mixtures and gelatin capsules. Journal of Food Composition and Analysis, 25(1), 83-87. https://doi.org/10.1016/j.jfca.2011.06.008

Casiraghi, M., Labra, M., Ferri, E., Galimberti, A. and De Mattia, F. (2010). DNA barcoding: A sixquestion tour to improve users' awareness about the method. Briefings in Bioinformatics, 11(4), 440-453. https://doi.org/10.1093/bib/bbq003

Che Man, Y.B., Aida, A.A., Raha, A.R. and Son, R. (2007). Identification of pork derivatives in food products by species-specific polymerase chain reaction (PCR) for halal verification. Food Control, 18(7), 885-889. https://doi.org/10.1016/ j.foodcont.2006.05.004

Chen, F-C., Hsieh, Y-H.P. and Brigdman, R.C. (1998). Monoclonal Antibodies to Porcine Thermal-Stable Muscle Protein for Detection of Pork in Raw and Cooked Meats. Journal of Food Science, 63(2), 201 $205 . \quad$ https://doi.org/10.1111/j.13652621.1998.tb15709.x

Cheng, J.-H., Chou, H.-T., Lee, M.-S. and Sheu, S.-C. (2016). Development of qualitative and quantitative PCR analysis for meat adulteration from RNA samples. Food Chemistry, 192, 336-342. https:// doi.org/10.1016/j.foodchem.2015.06.094

Cordella, C., Moussa, I., Martel, A.C., Sbirrazzuoli, N. and Cuvelier, L.L. (2002). Recent developments in food characterization and adulteration detection: technique-oriented perspectives. Journal of Agriculture and Food Chemistry, 50, 1751-1764. https://doi.org/10.1021/jf011096z

El Sheikha, A.F. (2019). DNA Foil: Novel technology for the rapid detection of food adulteration. Trends in Food Science and Technology, 86, 544-552. https:// doi.org/10.1016/j.tifs.2018.11.012

Galimberti, A., De Mattia, F., Losa, A., Bruni, I., Federici, S., Casiraghi, M. and Labra, M. (2013). DNA barcoding as a new tool for food traceability.
Food Research International, 50(1), 55-63. https:// doi.org/10.1016/j.foodres.2012.09.036

Gao, W., Huang, H., Zhang, Y., Zhu, P., Yan, X., Fan, J. and Chen, X. (2017). Recombinase polymerase amplification-based assay for rapid detection of Listeria monocytogenes in food samples. Food Analytical Methods, 10(6), 1972-1981. https:// doi.org/10.1007/s12161-016-0775-0

Gao, Z., Liu, Y., Wang, X., Wei, X. and Han, J. (2019). DNA mini-barcoding: A derived barcoding method for herbal molecular identification. Frontiers in Plant Science, 2019, 00987. https://doi.org/10.3389/ fpls.2019.00987

Geng, Y., Liu, S., Wang, J., Nan, H., Liu, L., Sun, X., Li, D., Liu, M., Wang, J. and Tan, K. (2018). Rapid detection of Staphylococcus aureus in food using a recombinase polymerase amplification-based assay. Food Analytical Methods, 11(10), 2847-2856. https://doi.org/10.1007/s12161-018-1267-1

Guo, Z., Chen, Z., Liu, X., Chen, J., Chen, G., Liu, Z., Yang, G. and Lan, Q. (2019). Detection of Listeria monocytogenes and Staphylococcus aureus via duplex recombinase polymerase amplification. Journal of Food Safety, 39(4), 1-6. https:// doi.org/10.1111/jfs.12628

Hafidz, M.M.M., Makatar, W-H., Adilan, H. and Nawawee, T. (2020). Detection of pork processed meat products by species-specific PCR for halal verification: Food fraud cases in Hat Yai, Thailand. Food Research, 4(S1), 244-249. https:// doi.org/10.26656/fr.2017.4(S1).S21

Hartati, Y.W., Suryani, A.A., Agustina, M., Gaffar, S. and Anggraeni, A. (2019). A gold nanoparticleDNA bioconjugate-based electrochemical biosensor for detection of Sus scrofa mtDNA in raw and processed meat. Food Analytical Methods, 12, 25912600. https://doi.org/10.1007/s12161-019-01593-6

Hebert, P.D.N., Ratnasingham, S. and deWaard, J.R. (2003). Barcoding animal life: Cytochrome c oxidase subunit 1 divergence among closely related species. Proceedings of the Royal Society B: Biological Science, 270, S96-S99. https://doi.org/10.1098/ rsbl.2003.0025

Hsieh, Y-H. P., Woodward, B.B. and Ho, S.H. (1995). Detection of Species Substitution in Raw and Cooked Meats Using Immunoassays. Journal of Food Protection, 58(5), 555-559. https:// doi.org/10.4315/0362-028X-58.5.555

Johnson, R. (2014). Food fraud and 'economically motivated adulteration' of food and food ingredients. USA: Congressional Research Service. https:// fas.org/sgp/crs/misc/R43358.pdf 
Karabasanavar, N.S., Singh, S.P., Kumar D. and Shebannavar, S.N. (2014). Detection of pork adulteration by highly specific PCR assay of mitochondrial D-loop. Food Chemistry, 145, 530534. https://doi.org/10.1016/j.foodchem.2013.08.084

Kersting, S., Rausch, V., Bier, F.F. and Von NickischRosenegk, M. (2014). Rapid detection of Plasmodium falciparum with isothermal recombinase polymerase amplification and lateral flow analysis. Malaria Journal, 13(1), 1-9. https:// doi.org/10.1186/1475-2875-13-99

Khaksar, R., Carlson, T., Schaffner, D.W., Ghorashi, M., Best, D., Jandhyala, S. and Amini, S. (2015). Unmasking seafood mislabeling in U.S. markets: DNA barcoding as a unique technology for food authentication and quality control. Food Control, 56, 71-76.

https://doi.org/10.1016/ j.foodcont.2015.03.007

Kumar, A., Kumar, R.R., Sharma, B.D., Gokulakrishnan, P., Mendiratta, S.K. and Sharma, D. (2015). Identification of species origin of meat and meat products on the DNA Basis: A review. Critical Reviews in Food Science and Nutrition, 55(10), 1340 $-1351$. https:// doi.org/10.1080/10408398.2012.693978

Kušec, I.D., Samac, D., Margeta, V., Radišić, Z., Vincek, D. and Kušec, G. (2017). Efficiency of PCR-RFLP and species specific PCR for identification of meat origin in dry sausages. Food analysis, food quality and nutrition. Czech Journal of Food Sciences, 35 (5), 386-391. https://doi.org/10.17221/243/2016CJFS

Levin, R.E., Ekezie, F.G.C. and Sun, D.W. (2018). DNA -based technique: Polymerase chain reaction (PCR). In Sun, D.-W. (Eds.). Modern Techniques for Food Authentication. $2^{\text {nd }}$ ed., p. 527-616. USA: Academic Press. https://doi.org/10.1016/B978-0-12-8142646.00014-1

Li, J. and Macdonald, J. (2015). Advances in isothermal amplification: Novel strategies inspired by biological processes. Biosensors and Bioelectronics, 64, 196211. https://doi.org/10.1016/j.bios.2014.08.069

Li, J., Pollak, N.M. and Macdonald, J. (2019). Multiplex detection of nucleic acids using recombinase polymerase amplification and a molecular colorimetric 7-segment display [Research-article]. ACS Omega, 4(7), 11388-11396. https:// doi.org/10.1021/acsomega.9b01097

Lin, C.C., Fung, L.L., Chan, P.K., Lee, C.M., Chow, K.F. and Cheng, S.H. (2014). A rapid low-cost highdensity DNA-based multi-detection test for routine inspection of meat species. Meat Science, 96(2, Part
A),
922-929.
https://doi.org/10.1016/

j.meatsci.2013.09.001

Luthy, J. (1999). Detection strategies for food authenticity and genetically modified foods. Food Control, 10(6), 359-361. https://doi.org/10.1016/ S0956-7135(99)00075-4

Maede, D. (2006). A strategy for molecular species detection in meat and meat products by PCR-RFLP and DNA sequencing using mitochondrial and chromosomal genetic sequences. European Food Research and Technology, 224, 209-217. https:// doi.org/10.1007/s00217-006-0320-2

Marikkar, J.M.N., Lai, O.M., Ghazali, H.M. and Che Man, Y.B. (2001). Detection of lard and randomized lard as adulterants in refined-bleached-deodorized palm oil by differential scanning calorimetry. Journal of American Oil Chemists' Society, 78(11), 1113-1119. https://doi.org/10.1007/s11746-001-0398 $-5$

Montiel-Sosa, J.F., Ruiz-Pesini, E., Montoya, J., Roncales, P., Lopez-Perez, M.J. and Perez-Martos, A. (2000). Direct and Highly Species-Specific Detection of Pork Meat and Fat in Meat Products by PCR Amplification of Mitochondrial DNA. Journal of Agricultural and Food Chemistry, 48, 2829-2832. https://doi.org/10.1021/jf9907438

Murinda, S.E., Ibekwe, A.M., Zulkaffly, S., Cruz, A., Park, S., Razak, N., Paudzai, F.M., Samad, L.A., Baquir, K., Muthaiyah, K., Santiago, B., Rusli, A. and Balkcom, S. (2014). Real-time isothermal detection of shiga toxin-producing Escherichia coli using recombinase polymerase amplification. Foodborne Pathogens and Disease, 11(7), 529-536. https://doi.org/10.1089/fpd.2013.1663

Naaum, A.M., Shehata, H.R., Chen, S., Li, J., Tabujara, N., Awmack, D., Lutze-Wallace, C. and Hanner, R. (2018). Complementary molecular methods detect undeclared species in sausage products at retail markets in Canada. Food Control, 84, 339-344. https://doi.org/10.1016/j.foodcont.2017.07.040

Paiva-Cavalcanti, M., Regis-da-Silva, C. and Gomes, Y. (2010). Comparison of real-time PCR and conventional PCR for detection of Leishmania (Leishmania) infantum infection: a mini-review. Journal of Venomous Animals and Toxins Including Tropical Diseases, 16(4), 537-542. https:// doi.org/10.1590/S1678-91992010000400004

Pestana, E.A., Belak, S., Diallo, A. Crowther, J.R. and Viljoen, G. J. (2010). Early, Rapid and Sensitive Veterinary Molecular Diagnostics-Real Time PCR Applications, p. 1-31. Switzerland: Springer. https:// doi.org/10.1007/978-90-481-3132-7

Piepenburg, O., Williams, C.H., Stemple, D.L. and 
Armes, N.A. (2006). DNA Detection Using Recombination Proteins. PLoS Biology, 4(7), 2-8. https://doi.org/10.1371/journal.pbio.0040204

Ram, J.L., Ram, M.L. and Baidoun, F.F. (1996). Authentication of Canned Tuna and Bonito by Sequence and Restriction Site Analysis of Polymerase Chain Reaction Products of Mitochondrial DNA. Journal of Agricultural and Food Chemistry, 44, 2460-2467. https:// doi.org/10.1021/jf950822t

Regan, F., Chapman, J. and Sullivan, T. (Eds.) (2012). Molecular Biological Techniques. Nanoparticles in Anti-Microbial Materials: Use and Characterisation, p. 194-196. United Kingdom: Royal Society of Chemistry. https://doi.org/10.1039/978184973526100194

Rohman, A. and Fadzillah, N.A. (2018). Lipid-based techniques used for halal and kosher food authentication. In Ali, M.E. and Nizar, N.N.A. (Eds.) Preparation and Processing of Religious and Cultural Foods, p. 393-407. USA: Woodhead Publishing. https://doi.org/10.1016/B978-0-08-101892-7.000213

Różycki, M., Chmurzyńska, E., Bilska-Zając, E., Karamon, J. and Cencek, T. (2018). Isoelectric Focusing of Proteins in the $\mathrm{pH}$ Gradient as a Tool for Identification of Species Origin of Raw Meat. Journal of Veterinary Research, 62(2), 151-159. https://doi.org/10.2478/jvetres-2018-0024

Santiago-Felipe, S., Tortajada-Genaro, L.A., Puchades, R. and Maquieira, A. (2014). Recombinase polymerase and enzyme-linked immunosorbent assay as a DNA amplification-detection strategy for food analysis. Analytica Chimica Acta, 811, 81-87. https://doi.org/10.1016/j.aca.2013.12.017

Sawyer, J., Wood, C., Shanahan, D., Gout, S. and McDowell, D. (2003). Real-time PCR for quantitative meat species testing. Food Control, 14 (8), 579-583. https://doi.org/10.1016/S0956-7135 (02)00148-2

Soares, S., Amaral, J.S., Oliveira, M.B.P.P. and Mafra, I. (2013). A SYBR Green real-time PCR assay to detect and quantify pork meat in processed poultry meat products. Meat Science, 94(1), 115-120. https://doi.org/10.1016/j.meatsci.2012.12.012

Staggemeier, R., Bortoluzzi, M., Heck, T.M. Da S., Spilki, F.R. and Almeida, S.E.D,M. (2015). Quantitative VS. Conventional PCR for Detection of Human Adenoviruses in Water and Sediment Samples. Revista Do Instituto de Medicina Tropical de São Paulo, 57(4), 299-303. https:// doi.org/10.1590/S0036-46652015000400005
Sulaiman, I. and Muid, H.A. (Ed.). (2009). Pengenalan kepada Kejuruteraan Genetik. In Konsep Genetik, p. 217-239. Malaysia: Dewan Bahasa dan Pustaka. [In Bahasa Malaysia].

Wang, W., Chen, K. and $\mathrm{Xu}, \mathrm{C}$. (2006). DNA quantification using EvaGreen and a real-time PCR instrument. Analytical Biochemistry, 356(2), 303305. https://doi.org/10.1016/j.ab.2006.05.027

Wang, Y., Zhu, W. and Levy, D.E. (2006). Nuclear and cytoplasmic mRNA quantification by SYBR green based real-time RT-PCR. Methods, 39(4), 356-362. https://doi.org/10.1016/j.ymeth.2006.06.010

Wolf, C. and Lüthy, J. (2001). Quantitative competitive (QC) PCR for quantification of porcine DNA. Meat Science, 57(2), 161-168. https://doi.org/10.1016/ S0309-1740(00)00088-7

Yan, L., Zhou, J., Zheng, Y., Gamson, A.S., Roembke, B.T., Nakayama, S. and Sintim, H.O. (2014). Isothermal amplified detection of DNA and RNA. Molecular BioSystems, 10(5), 970-1003. https:// doi.org/10.1039/c3mb70304e

Yusop, M.H.M., Mustafa, S., Man, Y.B.C., Omar, A.R. and Mokhtar, N.F.K. (2012). Detection of raw pork targeting porcine-specific mitochondrial cytochrome $\mathrm{B}$ gene by molecular beacon probe real-time polymerase chain reaction. Food Analytical Methods, 5(3), 422-429. https://doi.org/10.1007/ s12161-011-9260-y

Zanoli, L.M. and Spoto, G. (2013). Isothermal amplification methods for the detection of nucleic acids in microfluidic devices. Biosensors, 3(1), 1843. https://doi.org/10.3390/bios3010018

Zeng, L., Wen, J., Fan, S., Chen, Z., Xu, Y., Sun, Y. and Li, Y. (2018). Identification of sea cucumber species in processed food products by PCR-RFLP method. Food Control, 90, 166-171. https://doi.org/10.1016/ j.foodcont.2018.02.048 